\title{
Organization Structure Municipally, Ready To The Organizational Incorporation Of The Information Technologies?
}

\author{
Israel Patiño Galván \\ Research Division of the Innovation Park - PILS \\ University La Salle Northwest, Mexico \\ J. Jesús Ceja Pizano \\ School Higher of Accounting and Administration \\ Polytechnique National Institute, Mexico
}

\begin{abstract}
The Information Technologies (IT) Have empowered and optimized human activities in various disciplines, including the local public administration, and this has resulted in process transparency, optimization of resources, collaboration in decision making, projections, optimization, among other advantages. However, it is necessary to have a technological infrastructure that guarantees the incorporation and permanence of these technologies in the long term, and more important, to have a specialized organizational structure that oversees planning, developing, implementing, projecting and collaborating in the evaluation Constantly of the processes, as well as of the technologies, that have an innovative impact in the operative and administrative processes of the municipal administration. However, in the municipal public administrations, these advantages have not been integrated, much less think about their permanence, for this, this article suggests a specialized organizational structure that can guarantee the use of IT in the long term. This proposal is supported by inductive and deductive methodologies, field research that was carried out in a sample of Mexican municipalities and their current organizational structures that are responsible for managing and operating IT.
\end{abstract}

Keywords: Organizational Structure, Information Technologies, Public Administration local.

\section{INTRODUCTION}

The municipal public administration is the direct contact with the citizens, local companies, among others, with respect to the public services that they receive as part of the constitutional attributions that are entrusted to the municipalities of the Mexican Republic. Due to this, and given the increase in the needs and services of the population, there is a greater demand, which means that the municipal authorities generate strategies to meet them in a satisfactory manner in its four dimensions: Government - Citizen, Government - Company, Government - Employee and Government - Government [1]. In this sense, Information Technology plays a crucial role in providing support in the care and monitoring of these needs and services. That they collaborate in the incorporation of the Information Technologies in the administrative and operative processes proper to the municipalities. Despite the efforts made by the municipalities, these have not been sufficient, so it is necessary to enhance the use of Information Technology, integrating them directly in the strategic decisions, to project current and future needs of the respective public services. From the above, it is important to propose a strategic organizational structure, where the incorporation, permanence and satisfactory evolution and long-term of Information Technologies, to enhance municipal administrative and operational activities are guaranteed. 
In this article, the antecedents of the organizational structures and the Information Technologies, as well as the international context of the incorporation of the IT in the public administration. Subsequently the results of documental and field research are presented, to conclude with the proposal of a specialized organizational structure and the conclusions of the present.

\section{BACKGROUND OF ORGANIZATIONAL STRUCTURES.}

Organizational structures emerged at the stage of the industrial revolution $(1760$ - 1840) with the growth of companies and with it the increase in the complexity to organize them, since it was not possible to administer them with little personnel, which made the assignment complicated Of functions, so that departments had to be expanded spontaneously and improvised, until the scientific administration appeared with Taylor [2], in which appeared the authority, responsibility and separation of the administrative process. Already for the twentieth century organizational structures dominated the field of organizational analysis, to optimize the processes and resources of companies, and has now moved to a stage of focusing the analysis on the environment of organizations, as processes of Growth, encompassing a broader range of phenomena involving organizations.

On the other hand, organizational structures form a core part of organizations, in they is identify the organization, execution and control of what is planned in the organization. In this sense, its functioning is based on theory as comparing an organizational structure with a building structure [3]. However, it would change that analogy by comparing organizational structures with the human body, by the fact that structures Think, evolve, grow and develop, where each of the departments / areas / departments / people collaborate to achieve the same goal, and where failure to do so damages the direct or indirect functioning of other areas, such as Is proposed by systems theory, which proposes to re conceptualize the phenomena within a global approach to achieve the interrelation and integration of the basic aspects or premises that every system, has an input, a process and product, is a unit Autonomous that is related to another superior system, that is able to adapt and to survive in its characteristic environment and that maintains a continuous exchange of matter, energy and information with the environment [4].

\section{Concepts of organizational structures}

\section{CONTEXT OF ORGANIZATIONAL STRUCTURES}

To be able to size the importance of the organizational structures, the following definitions are presented per the following authors:

- It is the distribution of people in different lines. Between the social positions that influence the role of them in their relations [5].

- It is a complex means of control that is produced and recreated continuously by the interaction but that determines, at the same time, that interaction: structures are constituted and constitutive [6].

- It is the way your work is divided and how these separate activities are coordinated and integrated. Conventional structures are generally represented in a diagram consisting of frames and connecting lines. They show who has the responsibility of who and who has authority [7]. 
- Represents and describes the relationships among members of the organization and which in turn serves to limit, guide and anticipate organizational activities, to increase the effectiveness of operations and results [8].

From the above it is concluded that an organizational structure is the segmentation of activities to achieve the execution of the previously planned activities, where the functions, obligations and authority of the members are determined, obtaining if the feedback between all the areas related to reach of the specific and general objectives of the organization.

\section{Types of organizational structures}

The type of structure is determined by the size of the organization and the staff that compose it, which is why it is crucial the forms of organization between each of the areas that comprise it. So, there are varied types of structures.

To achieve a simple and easy to understand identification is presented in Table 1., the following classification [9]:

Table 1. Main Organizational Structures

\begin{tabular}{|l|l|}
\hline Forms & Structures \\
\hline \multirow{3}{*}{ Simple } & Simple \\
\cline { 2 - 2 } Classic complexes & Functional \\
\hline & Divisional \\
\cline { 2 - 2 } & Matrix \\
\hline
\end{tabular}

Source: Organization of companies [9]

To know these structures are conceptualized, and it presenting the factors that affect the organizational design called "contingency factor". The following are the main organizational structures [10]:

1. Simple structure. It can be considered as a non-formal structure. In a simple structure, the organization is governed by the personal control of an individual. It is the type of organization common to many small businesses. There is usually an owner who assumes most of the managerial responsibility, perhaps with a partner or an assistant. However, there is little division of managerial responsibility, and probably an unclear definition of who is responsible in situations where more than one person is involved.

2. Functional structure. It is an organizational design that groups occupational specialties and is based on the primary activities to be performed, such as production, finance and accounting, marketing and personnel. It is the functional approach and departmentalization applied to the entire organization. It is used in organizations of an industrial type that emphasizes the principles or parameters of the horizontal design and that looks for the administrative rationality and the increase of the economic productivity.

3. Divisional structure. It is the one that divides the organization into units or divisions, partially autonomous, depending on the products, services, geographic areas or processes of the company. The division usually arises as an attempt to overcome the problems of functional structures in solving the problems derived from diversification.

4. Matrix structure. A matrix structure is a combination of structures that often take the form of geographical and product divisions, or functional and divisional structures that operate simultaneously. Matrix structures may be preferred because there is more than one conditioning factor of the type of structure which renders functional structures or functional or divisional structures inadequate. The matrix model can be considered as 
an important linking or coordination system in the organization, integrating several lateral relationships. Derived from the above, a comparative table between the different main organizations structures is presented below.

Table 2. Comparison of main organizational structures

\begin{tabular}{|l|l|l|}
\hline Structure & Strengths & Weak points \\
\hline \multirow{3}{*}{ Simple } & Flexibility & Owner / manager's dependency \\
\cline { 2 - 3 } & Sense of mission & Little specialization \\
\hline \multirow{2}{*}{ Finctional } & Specialization & Low flexibility \\
\cline { 2 - 3 } & Formalization & Inadequate in diversified companies \\
\hline \multirow{3}{*}{ Matrix } & Orientation to the environment & Information Asymmetries \\
\cline { 2 - 3 } & Existence of profit centers & Problems of coordination of divisions \\
\cline { 2 - 3 } & Support for creativity and innovation & Double authority \\
\hline
\end{tabular}

Source: The evolution of the design and the organizational structure [10], p.38

Continuing with organizational structures, new forms of organization are presented [11] (See Table 3).

Derived from Table 3, it will be emphasized on the network and virtual structures, since the present work focuses on these.

Table 3. Proposals for new organizational structures

\begin{tabular}{|l|l|}
\hline Denomination & Author \\
\hline Adhocracy & Mintzberg [12]; Malone y Rockart [13] \\
\hline Post-industrial organization & Huber [14] \\
\hline Circular organization & Ackoff [15] \\
\hline Internal market & Malone, Yates y Benjamín [16]; Ouchi [17] \\
\hline Heterarchy & Hedlund [18] \\
\hline Organization in Networking & $\begin{array}{l}\text { Miles y Snow [19]; Eccles y Crane [20]; Ghoshal y } \\
\text { Barlett [21] }\end{array}$ \\
\hline Federal organization & Handy [22] \\
\hline Knowledge-based organization & Badaracco [23] \\
\hline Cluster organization & Milis [24] \\
\hline Open corporation & Wagner [25] \\
\hline Virtual organization & Davidow y Malone [26]; Bridges [27] \\
\hline Internal network & Snow, Miles y Coleman [28] \\
\hline Infinitely flat organization & Quinn [29] \\
\hline Technocracy & Burris [30] \\
\hline Horizontal organization & Ostroff y Smith [31] \\
\hline Post-bureaucratic form & Heckscher [32] \\
\hline N-form & Hedlund [33] \\
\hline Lateral organization & Galbraith [34] \\
\hline Hypertextual Structures & Nonaka y Takeuchi [35] \\
\hline Platform or flat structure & Ciborra [36] \\
\hline T-form & Lucas [37] \\
\hline Cellular & Miles, Snow, Mathews, Miles y Coleman [38] \\
\hline Fractal Structures & Morales [39] \\
\hline
\end{tabular}

Source: The evolution of the organizational forms, from Simple Structure to Organization in Network and Virtual Organization [11] 


\section{Organizational network structure.}

It represents the fragmentation of the company in the segregation of activities, substituting the activities integrated in a conventional way by agreements between companies and by all type of link between companies (See Illustration 1). The network organization would be defined as; "A framework that serves as a basis for the simultaneous, coordinated, balanced and integrated operation of more than one organization, since it presents the various inter-organizational relationships existing between the different elements that make up." These interrelations include technicians and behavior, based on the conditioning factors and the components that influence their own design [10].

\section{Illustration 1. Organizational Structure of Nwtwork}

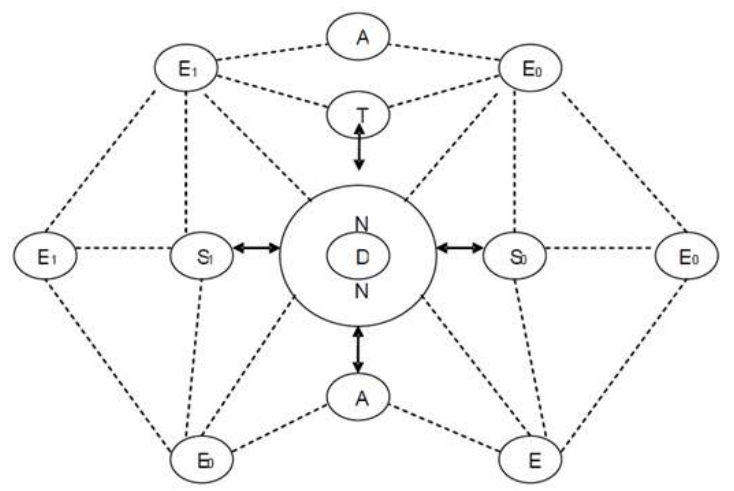
A. Alliances
D. General Direction E. Enterprice
Si. Outsourcing (input)
N. Professional core
So. Outsourcing (output)
T. Flexible Work

Source: The evolution of the design and the organizational structure [10], p.77

Derived from the above the companies and organizations are part and are related in the following way (See Table 4)

Table 4. Types of networks in which people and organizations are part

\begin{tabular}{|l|l|l|l|}
\hline Concept & People & Knowledge & Organizations \\
\hline $\begin{array}{l}\text { People } \\
\text { Link } \\
\text { Phenomenon } \\
\text { Learning }\end{array}$ & $\begin{array}{l}\text { Social network } \\
\text { Who knows to whom } \\
\text { Social structure } \\
\text { Knowledge } \\
\text { Link } \\
\begin{array}{l}\text { Phenomenon } \\
\text { Learning }\end{array}\end{array}$ & $\begin{array}{l}\text { Knowledge Network } \\
\text { Who knows what }\end{array}$ & $\begin{array}{l}\text { Culture } \\
\text { Whotwork } \\
\text { Who works where } \\
\text { Organizational demography } \\
\text { Rotation based learning }\end{array}$ \\
\hline $\begin{array}{l}\text { Organizations } \\
\text { Link } \\
\text { Phenomenon }\end{array}$ & ---- & $\begin{array}{l}\text { Information Network } \\
\text { What informs what } \\
\text { Intellectual training }\end{array}$ & $\begin{array}{l}\text { Network of competences } \\
\text { What is where } \\
\text { Basic skills } \\
\text { I \& D and strategic learning }\end{array}$ \\
\hline Learn & --- & --- & $\begin{array}{l}\text { Inter-organizational network } \\
\text { Organizational unions } \\
\text { Industry-level structure }\end{array}$ \\
\hline
\end{tabular}

Fuente: The evolution of organizational forms, from Simple Structure to Networking and Virtual Organization. [10], p. 78, by Carry [40]

One observed trend, is that organizations are disintegrating their activities, due inter alia to the lower costs of electronic interconnection with other companies, suppliers or customers, which is causing companies to gradually shift towards more market-based structural configurations, with some specialized functions carried, in hierarchical organizations, and point out the 
challenge for companies to effectively manage such interdependence [41]. In this sense, a dynamic network is the cause and result of the current competitive environment. The characteristics of this dynamic network are: vertical disaggregation (activities that were previously carried out within an organization are now done outside, by independent organizations). Networks may be more or less complex and dynamic depending on competitive circumstances), such as: a. Intermediaries (business groups agree through intermediaries since the activities are done in a single organization) b. Market mechanisms (the main functions are carried out jointly, employing market mechanisms rather than plans and control), c. Contracts and payouts are used more than reports of progress or personal supervision, d. State-of-the-art information systems (computerized information systems with up-to-date information) [19].

\section{Virtual Organizational Structure}

Geographically dispersed, temporary or permanent set of individuals, groups, organizational units, or complete organizations dependent on electronic unions to complete a productive process [42]. It is important to emphasize the importance of Information and Communication Technologies for the effectiveness of the activities carried out in the virtual organization [11] (See Illustration 2 and 3).

\section{Illustration 2. Evolution of the traditional structure to the virtual}

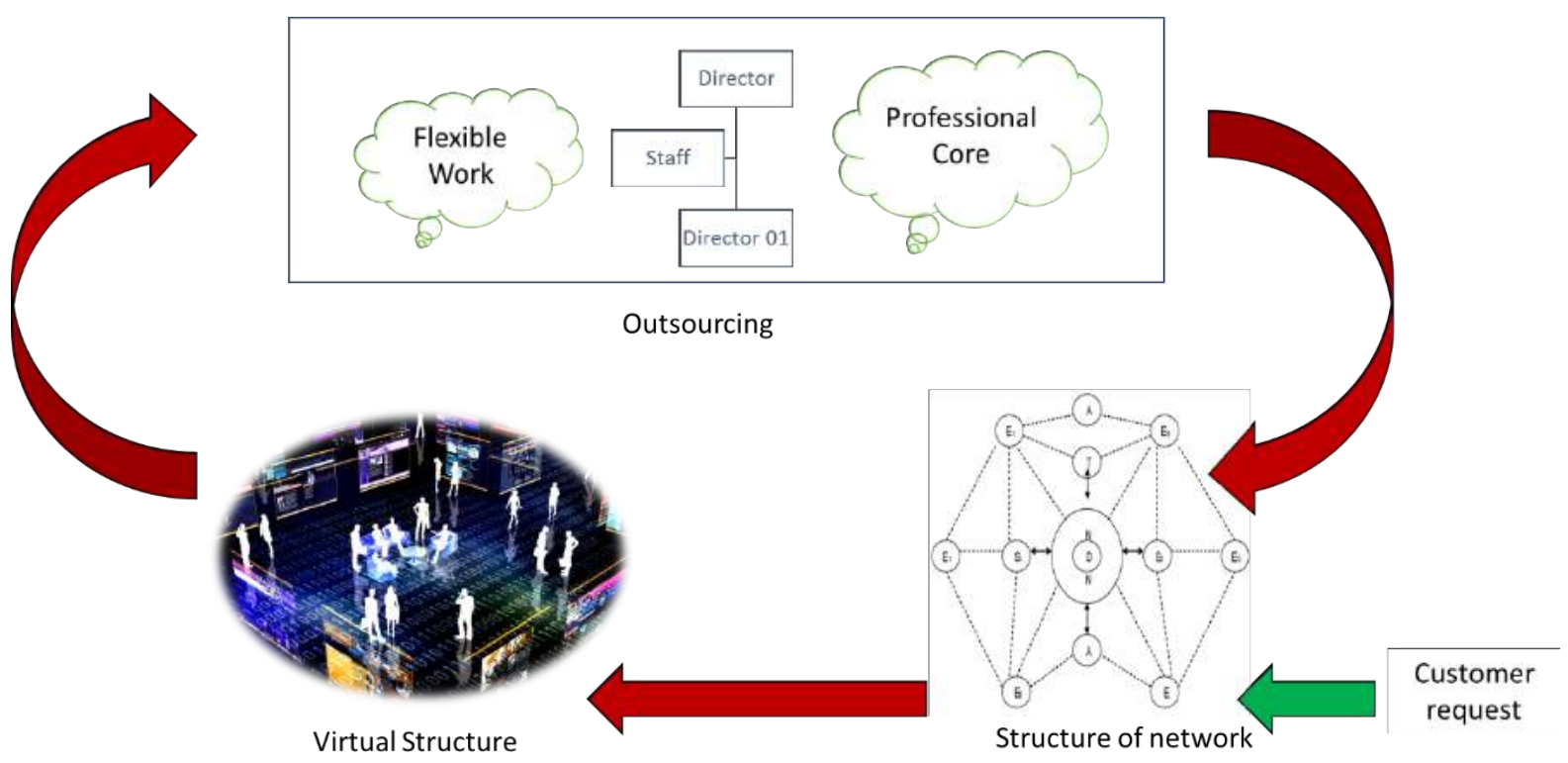

*Image of virtual structure retrieved

From:http://eloraculomundial.blogspot.mx/2015/02/vivimos-en-un-mundo-virtual-tipomatrix.html, 26/12/2016, con fines demostrativos

Source: own, from [10], [11] 


\section{Illustration 3. Characteristics of the virtual organization}

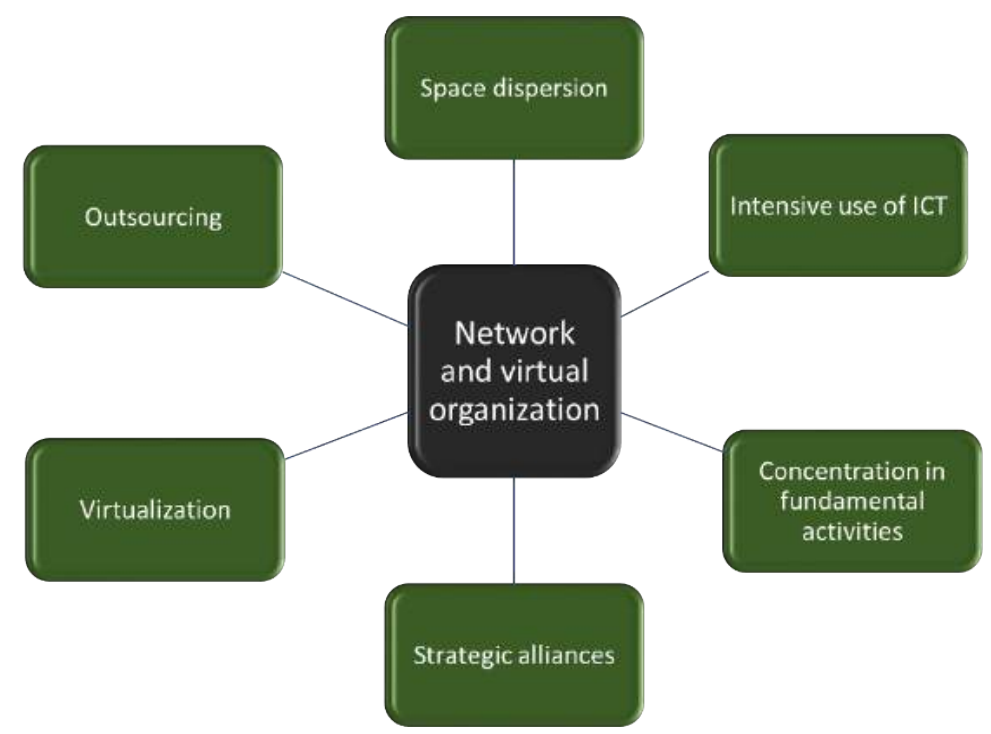

Source: The evolution of organizational forms, from Simple Structure to Networking and Virtual Organization [11], p. 83

Considering the current situation of the organizations, it is suggested to add 3 characteristics to the virtual organization, as shown in Illustration 4.

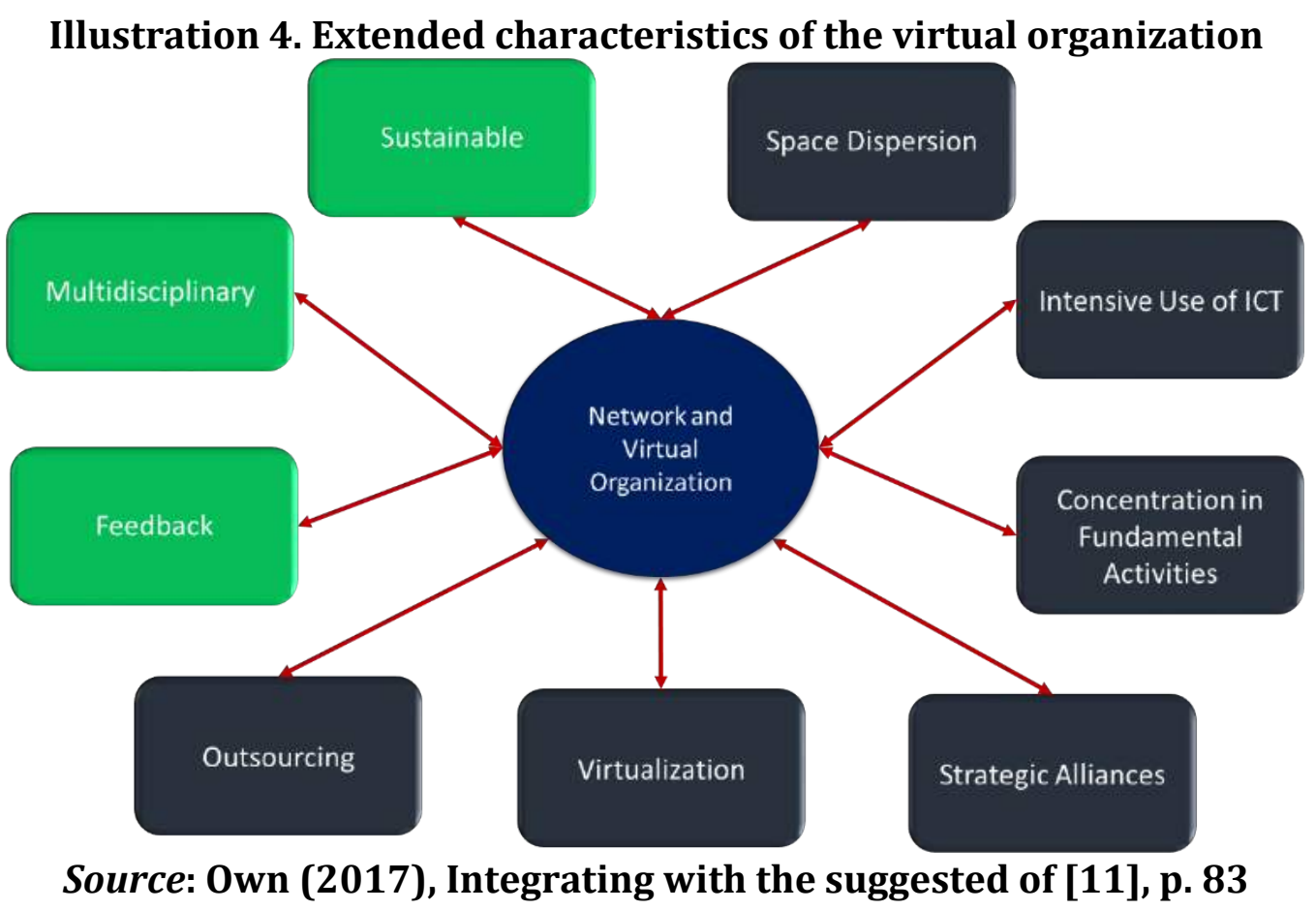

Finally, several types of virtual organizations are considered, as shown in Table 5, which help to understand their dimension [43]: permanent virtual organizations, virtual teams, virtual projects and temporary virtual organizations. In these the double dimension of the concept (internal and external) and the generality of its application is observed, since they are gathered from structures formed ad-hoc by work teams to networks of permanent companies that form a permanent virtual organization [11]. 
Table 5. Types of Virtual Organizational Structures

\begin{tabular}{|c|c|c|c|c|}
\hline Concept & Virtual Teams & Virtual Projects & $\begin{array}{l}\text { Virtual } \\
\text { Organization } \\
\text { Temporaly } \\
\end{array}$ & $\begin{array}{l}\text { Permanent } \\
\text { Organizations }\end{array}$ \\
\hline $\begin{array}{l}\text { Scope of } \\
\text { Internal } \\
\text { participation }\end{array}$ & $\begin{array}{l}\text { Internal, towards } \\
\text { an organizational } \\
\text { function or } \\
\text { departmental unit }\end{array}$ & $\begin{array}{l}\text { Between functions and } \\
\text { organizations }\end{array}$ & $\begin{array}{l}\text { Between } \\
\text { organizations }\end{array}$ & $\begin{array}{l}\text { Between } \\
\text { organizations }\end{array}$ \\
\hline Members & Small, local & Undetermined & Broad Typically & $\begin{array}{l}\text { Small Typically but } \\
\text { scalable }\end{array}$ \\
\hline Missions & $\begin{array}{l}\text { Equipment for } \\
\text { specific and } \\
\text { continuous tasks }\end{array}$ & $\begin{array}{l}\text { Multiple } \\
\text { representatives of the } \\
\text { organization working } \\
\text { on specific projects }\end{array}$ & $\begin{array}{l}\text { Multiple roles } \\
\text { responding to a } \\
\text { market } \\
\text { opportunity }\end{array}$ & $\begin{array}{l}\text { All the functions of } \\
\text { an organization }\end{array}$ \\
\hline $\begin{array}{l}\text { Project } \\
\text { duration }\end{array}$ & $\begin{array}{l}\text { Members change, } \\
\text { but the form is } \\
\text { permanent }\end{array}$ & Temporary & Temporary & Permanent \\
\hline Use of ICT & $\begin{array}{l}\text { Connectivity, } \\
\text { sharing } \\
\text { knowledge }\end{array}$ & Data Sharing & $\begin{array}{l}\text { Shared } \\
\text { Infrastructure }\end{array}$ & $\begin{array}{ll}\text { Channel for } & \\
\text { marketing and the } \\
\text { distribution, } \\
\text { replacing } \\
\text { physical the } \\
\text { infrastructure }\end{array}$ \\
\hline
\end{tabular}

Source: The evolution of organizational forms [11], p. $78 \&[43]$.

\section{Contexto De Las Tecnologías De La Información En El Ámbito De La Administración Pública}

In the international context, regarding the use of Information Technology and strategic organizational structures in public administration. The United Nations [44] has defined a framework for the evolution of Electronic Government at four levels of maturity, which has served as a reference for countries to define their own models, these levels are: 1. Emerging level, 2. Level Improved, 3. Transactional level and 4. Connected level. In this case, the municipalities of Mexico are located between the emerging level and in some at an improved level. On the other hand, in e-government forums of the Organization of American States [45], the importance of the models of maturity of an Electronic Government is framed. In this sense, the Organization for Economic Cooperation and Development [46] conducts studies and generates proposals for the satisfactory evolution in the use of technologies and their adequate instrumentation, relying on organizational structures for their operation. The Economic Commission for Latin America and the Caribbean [47] as part of the UN, likewise makes contributions and recommendations towards efficient innovation policies in public administration.

In the Mexican context, the Federal Government in the National Development Plan according to the Government of the Republic of Mexico [48] establishes the National Digital Strategy to "foster the adoption and development of Information and Communication Technologies, An effective government that inserts Mexico into The Knowledge Society, in addition to consolidating a government that is productive and effective in achieving its objectives, through an adequate rationalization of resources, recognition of merit, replication of best practices and implementation of automated management systems. " Replicated this strategy, as a process that is under development. However, the municipalities have lagged, as they do not have a specialized organizational structure to collaborate with the successful implementation of Information Technology. In relation to the national collaborative efforts, on this subject, it is the National Institute for Federalism and Municipal Development [49], making contributions in 
the organizational sense - strategic and technological. On the other hand, the National Council of Science and Technology (CONACYT) frequently collaborates with incentives to carry out research that collaborates with this effort. This implies an evolution not only organizational and technological but also cultural and education, since the incorporation of Information Technology in public management impacts both public bodies and society.

\section{METHODOLOGIES OF THE INVESTIGATION}

On the other hand, the methodologies of the scientific and technologic research that are they will employ are: Analysis - Synthesis, Induction and deduction, and finally the systemic functional structural:

- Analysis - Synthesis. Analysis is a theoretical process through of the complex whole. It decomposes in different parts and qualities. This allows the mental division of whole in multiple relations and components. The synthesis, establishes mentally the union among the parts previously analyzed and discover it's the essential relation and general characteristics. The synthesis produces on the results previously obtained in the analysis and allow the systematization of the knowledge [50]

- Induction -Deduction. These are theorists process of importance fundamental to the research, so that, for understand is necessary explain each one Induction, is a process through which, starting to facts similar is performed the general propositions, to helping to the formulation of the hypothesis. This process of the research always is in union to the deduction. Otherwise, the deduction form part, of the dialectic knowledge and the reality indissolubly [51]

- Systemic functional structural. Their evidence action the interrelationship of ideas, connection of concepts, systems of recommendations and union of methodologies and strategies, is become in an important via for the explain of the object of research.

\section{Determination of the sample}

\section{INVESTIGACIÓN DE CAMPO}

For the determination of the sample the type of population was analyzed, which was integrated by the 2,456 municipalities of the Mexican Republic and that to take a significant sample was used the simple stratified sampling and cualitative analyses (variables) like:

- Gross domestic product

- Total population

- Grade Level Average

- Housing with Internet

Once the variables and the technique for the determination of the sample were defined, the calculation was make. 


\section{Equiation:}

$$
n=\frac{Z^{2} p q N}{N E^{2}+Z^{2} p q}
$$

Where:

$\mathrm{n}=$ Theoretical quantity of elements of the sample ( $i ?)$

$\mathrm{Z}=$ Reliability (1.96)

$\mathrm{p}=$ Percentage that meets the characteristics of the population $(93 \%)$

$q=$ Percentage that does not meet the characteristics of the population (7\%)

$\mathrm{N}=$ Population $(2,456)$

$\mathrm{E}=$ Error assumed $(5 \%)$

Substituting values into the equation:

$$
n=\frac{(1.96)^{2} *(0.93 * 0.07) * 2456}{\left(2456 *(0.05)^{2}\right)+(2456)^{2} *(0.93) *(0.07)}=96.12
$$

The sample to be studied is 96 (rounded) municipalities throughout the Mexican Republic. After finding the number of samples, an analysis of the variables was carried out, to include in the study municipalities to consider the participation of all the States of the Mexican Republic. For this, Table 6 is presented in which the analysis is shown. 
Table 6. Analysis of variables by municipality to determine the selection of samples

\begin{tabular}{|c|c|c|c|c|}
\hline No. & State & $\begin{array}{l}\text { Number } \\
\text { Municipality }\end{array}$ & $\begin{array}{l}\text { Relative } \\
\text { Frequency }\end{array}$ & $\begin{array}{l}\text { Relative } \quad \text { cumulative } \\
\text { frequency }\end{array}$ \\
\hline 1 & Aguas Calientes & 11 & $0.45 \%$ & $0.45 \%$ \\
\hline 2 & Baja California & 5 & $0.20 \%$ & $0.65 \%$ \\
\hline 3 & $\begin{array}{ll}\text { Baja } & \text { California } \\
\text { Sur } & \end{array}$ & 5 & $0.20 \%$ & $0.86 \%$ \\
\hline 4 & Campeche & 11 & $0.45 \%$ & $1.30 \%$ \\
\hline 5 & Chiapas & 118 & $4.80 \%$ & $6.11 \%$ \\
\hline 6 & Chihuahua & 67 & $2.73 \%$ & $8.84 \%$ \\
\hline 7 & Ciudad de México & 16 & $0.65 \%$ & $9.49 \%$ \\
\hline 8 & Coahuila & 38 & $1.55 \%$ & $11.03 \%$ \\
\hline 9 & Colima & 10 & $0.41 \%$ & $11.44 \%$ \\
\hline 10 & Durango & 39 & $1.59 \%$ & $13.03 \%$ \\
\hline 11 & Estado de México & 125 & $5.09 \%$ & $18.12 \%$ \\
\hline 12 & Guanajuato & 46 & $1.87 \%$ & $19.99 \%$ \\
\hline 13 & Guerrero & 81 & $3.30 \%$ & $23.29 \%$ \\
\hline 14 & Hidalgo & 84 & $3.42 \%$ & $26.71 \%$ \\
\hline 15 & Jalisco & 125 & $5.09 \%$ & $31.80 \%$ \\
\hline 16 & Michoacán & 113 & $4.60 \%$ & $36.40 \%$ \\
\hline 17 & Morelos & 33 & $1.34 \%$ & $37.74 \%$ \\
\hline 18 & Nayarit & 20 & $0.81 \%$ & $38.56 \%$ \\
\hline 19 & Nuevo León & 51 & $2.08 \%$ & $40.64 \%$ \\
\hline 20 & Oaxaca & 570 & $23.21 \%$ & $63.84 \%$ \\
\hline 21 & Puebla & 217 & $8.84 \%$ & $72.68 \%$ \\
\hline 22 & Querétaro & 18 & $0.73 \%$ & $73.41 \%$ \\
\hline 23 & Quintana Roo & 9 & $0.37 \%$ & $73.78 \%$ \\
\hline 24 & San Luis Potosí & 58 & $2.36 \%$ & $76.14 \%$ \\
\hline 25 & Sinaloa & 18 & $0.73 \%$ & $76.87 \%$ \\
\hline 26 & Sonora & 72 & $2.93 \%$ & $79.80 \%$ \\
\hline 27 & Tabasco & 17 & $0.69 \%$ & $80.50 \%$ \\
\hline 28 & Tamaulipas & 43 & $1.75 \%$ & $82.25 \%$ \\
\hline 29 & Tlaxcala & 60 & $2.44 \%$ & $84.69 \%$ \\
\hline 30 & Veracruz & 212 & $8.63 \%$ & $93.32 \%$ \\
\hline 31 & Yucatán & 106 & $4.32 \%$ & $97.64 \%$ \\
\hline 32 & Zacatecas & 58 & $2.36 \%$ & $100.00 \%$ \\
\hline \multicolumn{2}{|c|}{ Total } & 2456 & $100.00 \%$ & \\
\hline \multicolumn{2}{|c|}{ Promedio } & 76.75 & 3 & \\
\hline
\end{tabular}

\section{Source: Own (2017)}

Once the segmentation was done, and considering the variables, it is confirmed that the sample is 96, taking 3 municipalities from each state of the Mexican Republic. The selected municipalities were (See Table 7). 
Table 7. Selection of the sample (Source: own 2017)

\begin{tabular}{|c|c|c|c|c|c|}
\hline No & State & Municipality & No & State & Municipality \\
\hline 1 & \multirow{3}{*}{ Aguas Calientes } & San José de Gracia & 49 & \multirow{3}{*}{ Morelos } & Tlalnepantla \\
\hline 2 & & Asientos & 50 & & Jantetelco \\
\hline 3 & & Aguascalientes & 51 & & Cuernavaca \\
\hline 4 & \multirow{3}{*}{ Baja California } & Playas de Rosarito & 52 & \multirow{3}{*}{ Nayarit } & Del Nayar \\
\hline 5 & & Ensenada & 53 & & San Pedro Lagunillas \\
\hline 6 & & Tijuana & 54 & & Tepic \\
\hline 7 & \multirow{3}{*}{$\begin{array}{l}\text { Baja California } \\
\text { Sur }\end{array}$} & Comondú & 55 & \multirow{3}{*}{ Nuevo León } & Mier y Noriega \\
\hline 8 & & Mulegé & 56 & & Melchor Ocampo \\
\hline 9 & & La Paz & 57 & & San Pedro Garza García \\
\hline 10 & \multirow{3}{*}{ Campeche } & Calakmul & 58 & \multirow{3}{*}{ Oaxaca } & Asunción Tlacolulita \\
\hline 11 & & Champotón & 59 & & Villa de Chilapa de Díaz \\
\hline 12 & & Campeche & 60 & & San Sebastián Tutla \\
\hline 13 & \multirow{3}{*}{ Coahuila } & Escobedo & 61 & \multirow{3}{*}{ Puebla } & Ahuatlán \\
\hline 14 & & Matamoros & 62 & & Tepeojuma \\
\hline 15 & & Monclova & 63 & & San Andrés Cholula \\
\hline 16 & \multirow{3}{*}{ Colima } & Ixtlahuacán & 64 & \multirow{3}{*}{ Querétaro } & Landa de Matamoros \\
\hline 17 & & Coquimatlán & 65 & & Huimilpan \\
\hline 18 & & Villa de Álvarez & 66 & & Corregidora \\
\hline 19 & \multirow{3}{*}{ Chiapas } & Sunuapa & 67 & \multirow{3}{*}{$\begin{array}{l}\text { Quintana } \\
\text { Roo }\end{array}$} & José María Morelos \\
\hline 20 & & Tzimol & 68 & & Tulum \\
\hline 21 & & Tuxtla Gutiérrez & 69 & & Cozumel \\
\hline 22 & \multirow{3}{*}{ Chihuahua } & Huejotitán & 70 & \multirow{3}{*}{$\begin{array}{l}\text { San Luis } \\
\text { Potosí }\end{array}$} & Santa Catarina \\
\hline 23 & & \begin{tabular}{|ll} 
San Francisco de \\
Conchos
\end{tabular} & 71 & & Ciudad del Maíz \\
\hline 24 & & Chihuahua & 72 & & San Luis Potosí \\
\hline 25 & \multirow{3}{*}{$\begin{array}{l}\text { Ciudad de } \\
\text { México }\end{array}$} & Milpa Alta & 73 & \multirow{3}{*}{ Sinaloa } & Badiraguato \\
\hline 26 & & La Magdalena Contreras & 74 & & Navolato \\
\hline 27 & & Benito Juárez & 75 & & \begin{tabular}{|l|} 
Culiacán \\
\end{tabular} \\
\hline 28 & \multirow{3}{*}{ Durango } & San Pedro del Gallo & 76 & \multirow{3}{*}{ Sonora } & Onavas \\
\hline 29 & & Pánuco de Coronado & 77 & & Etchojoa \\
\hline 30 & & Durango & 78 & & Hermosillo \\
\hline 31 & \multirow{3}{*}{ Guanajuato } & Atarjea & 79 & \multirow{3}{*}{ Tabasco } & Jonuta \\
\hline 32 & & Apaseo el Alto & 80 & & Teapa \\
\hline 33 & & Guanajuato & 81 & & Centro \\
\hline 34 & & Tlacoapa & 82 & & San Nicolás \\
\hline 35 & Guerrero & Leonardo Bravo & 83 & Tamaulinas & Antiguo Morelos \\
\hline 36 & Guerrero & $\begin{array}{|lll|}\begin{array}{l}\text { Chilpancingo } \\
\text { Bravo }\end{array} & \text { de } & \text { los } \\
\end{array}$ & 84 & & Ciudad Madero \\
\hline 37 & & Juárez Hidalgo & 85 & & Españita \\
\hline 38 & Hidalgo & Mineral del Chico & 86 & Tlaxcala & \begin{tabular}{|lll}
$\begin{array}{l}\text { Contla } \\
\text { Cuamatzi }\end{array}$ & de & Juan \\
\end{tabular} \\
\hline 39 & & Pachuca de Soto & 87 & & Tlaxcala \\
\hline 40 & & Tuxcacuesco & 88 & & Aquila \\
\hline 41 & Jalisco & Teocaltiche & 89 & Veracruz & \begin{tabular}{|ll} 
Manlio & Fabio \\
Altamirano & \\
\end{tabular} \\
\hline 42 & & Zapopan & 90 & & Boca del Río \\
\hline 43 & & San José del Rincón & 91 & & Chacsinkín \\
\hline 44 & $\begin{array}{l}\text { Estado } \\
\text { Móyico }\end{array}$ & Ayapango & 92 & Yucatán & Santa Elena \\
\hline 45 & & Metepec & 93 & & Mérida \\
\hline 46 & & Tzitzio & 94 & & Melchor Ocampo \\
\hline 47 & Michoacán & Gabriel Zamora & 95 & Zacatecas & Apozol \\
\hline 48 & & Morelia & 96 & & Zacatecas \\
\hline
\end{tabular}




\section{RESULTS OF DOCUMENTARY AND FIELD RESEARCH}

The research was done in a mixed way, the first through field research and the second through documentary research carried out on the web pages of the selected municipal governments, as well as official websites, where is identified the type of organizational structure that Has the municipalities. Derived from this second, the results obtained are as follows (see Table 8):

Table 8. Type of Municipal Structures

\begin{tabular}{|l|l|l|}
\hline Type of Organizational Structure & Sample & Percentage \\
\hline Divisional & 9 & $9 \%$ \\
\hline Functional & 65 & $68 \%$ \\
\hline Matrix & 1 & $1 \%$ \\
\hline Simple & 21 & $22 \%$ \\
\hline Total & 96 & $100 \%$ \\
\hline
\end{tabular}

Source: Own (2017)

\section{Graphic 1. Representation of municipal organic structures}

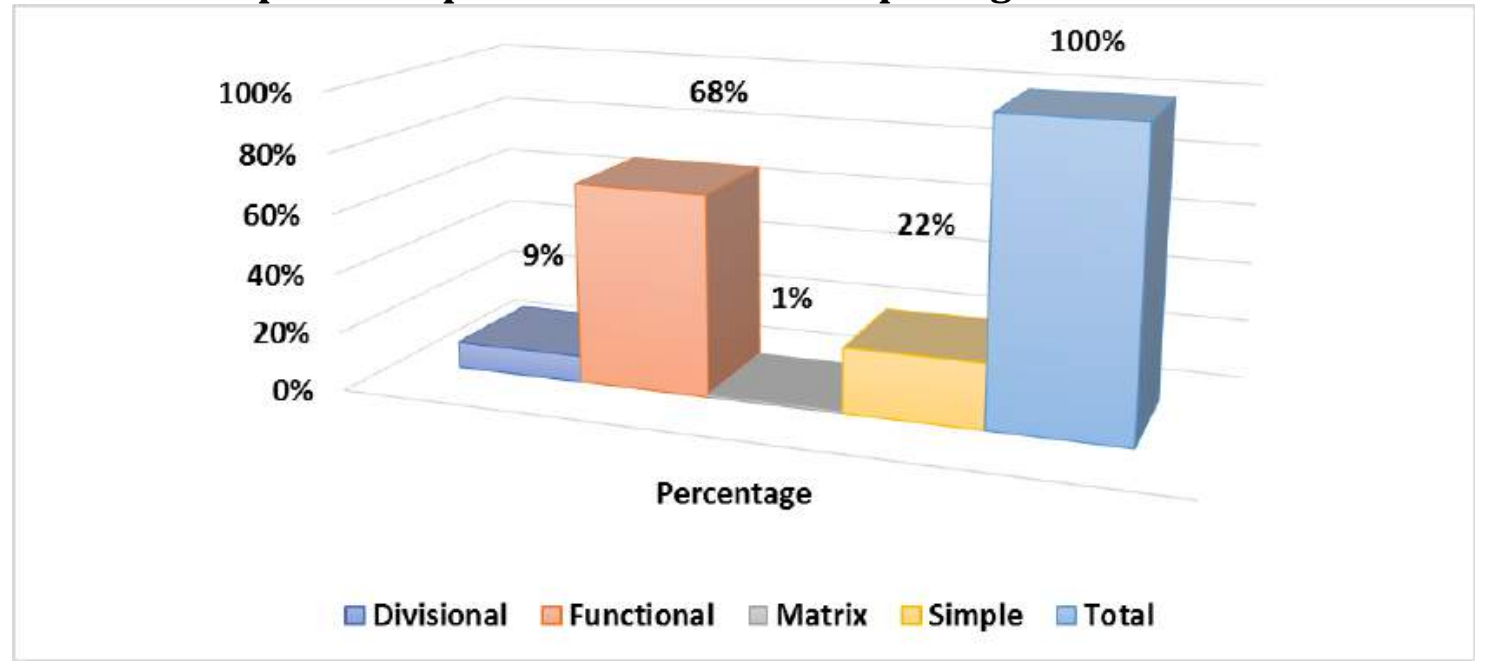

Soucer: Own (2017), according to the Table 8

As can be seen in Table 8 and Graphic 1,68\% of municipalities use a Functional organizational structure, while $22 \%$ use simple structures, finally, $9 \%$ of municipalities have divisional structures and only $1 \%$ matrix.

By performing a qualitative (complementary to the qualitative) analysis, the behavior analyzed in these results indicates that the more complex the organization goes from a Simple to a Functional, from Functional to Divisional and from Divisional to Matrix structure.

On the other hand, entering the analysis on whether the organizational structures contemplate an area on Information Technologies or related, the result can be visualized in the Table 9. 
Galván, I. P., \& Pizano, J. C. (2017). Organization Structure Municipally, Ready To The Organizational Incorporation Of The Information Technologies? Advances in Social Sciences Research Journal, 4(4) 125-145

Table 9. Areas identified with Information Technology or related functions, within the municipal organizational structures.

\begin{tabular}{|l|l|l|}
\hline Description of the area & Frequency & $\begin{array}{l}\text { Frecuencia } \\
\text { relativa }\end{array}$ \\
\hline Systems administrator & 1 & $1 \%$ \\
\hline Computer and Asset Control Coordination & 1 & $1 \%$ \\
\hline $\begin{array}{l}\text { Department of Digital Government / Information Services } \\
\text { Department }\end{array}$ & 1 & $1 \%$ \\
\hline Department of Information Systems & 2 & $2 \%$ \\
\hline Department of Computer Systems & 1 & $1 \%$ \\
\hline Department of Systems Technology & 1 & $1 \%$ \\
\hline Computer Department & 2 & $2 \%$ \\
\hline Department Systems and Maintenance & 1 & $1 \%$ \\
\hline Information Management & 2 & $2 \%$ \\
\hline Directorate of Informatics and Technological Systems & 1 & $1 \%$ \\
\hline Systems Management & 2 & $2 \%$ \\
\hline Systems and Information Management & 1 & $1 \%$ \\
\hline Technology Direction & 1 & $1 \%$ \\
\hline Direction of Information Technologies & 3 & $3 \%$ \\
\hline Direction General of Information and Communication Technologies & 1 & $1 \%$ \\
\hline Computing & 1 & $1 \%$ \\
\hline IT and Social Communication & 1 & $1 \%$ \\
\hline Computer and Systems & 1 & $1 \%$ \\
\hline No Information Technology or Similar Area & 71 & $74 \%$ \\
\hline Unit of Information Technologies & 1 & $1 \%$ \\
\hline Total & 96 & $100 \%$ \\
\hline
\end{tabular}

Source: Own (2017)

As can be seen in Table 9, 74\% of the municipalities in the sample do not have an area assigned to attend functions on Information Technology (IT). The rest is dispersed between coordinations, departments and Unit of Information Technologies as shown in Table 10.

Table 10. Grouping of areas with functions of Information Technologies within the structures municipal organizations

\begin{tabular}{|l|l|l|}
\hline Description of the area & Units & Percentage \\
\hline Leadership & 1 & $1 \%$ \\
\hline Coordination & 1 & $1 \%$ \\
\hline Department & 8 & $8 \%$ \\
\hline Direction & 11 & $11 \%$ \\
\hline Unit & 4 & $4 \%$ \\
\hline $\begin{array}{l}\text { Without Information Technology or Similar } \\
\text { Area }\end{array}$ & 71 & $74 \%$ \\
\hline Total & 96 & $100 \%$ \\
\hline
\end{tabular}

Source: Own (2017)

It is important to identify the department and the hierarchical level assigned to IT functions since IT will have greater responsibilities, obligations, authority and interference in decision making. As can be seen in Table 10 and Graph 2. Only $11 \%$ of the sample is assigned to one 
address, and the others have hierarchy of lower levels so their responsibilities, obligations, and decision making have less authority.

\section{Graphic 2. Grouping of areas with functions of Information Technologies within the structures municipal organizations}

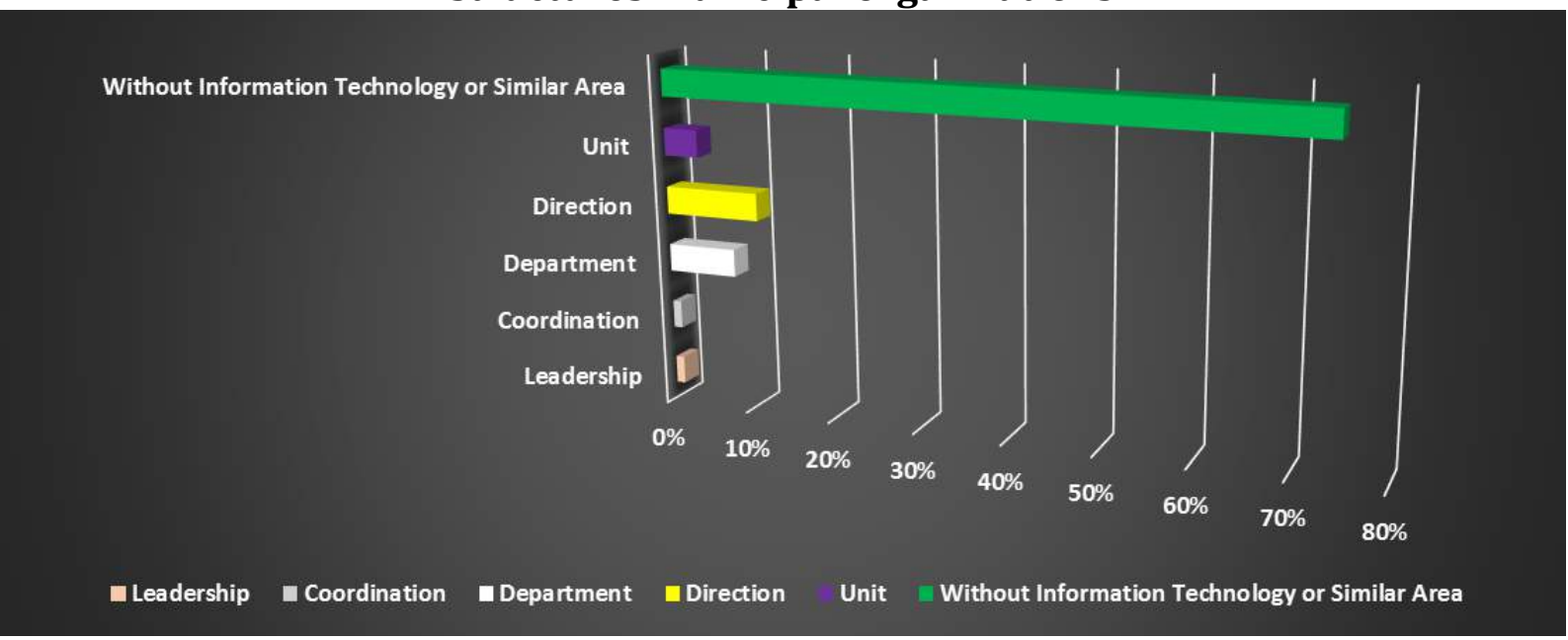

Source: Own (2017), according to Table 10

Table 11. Direct reporting areas of IT

\begin{tabular}{|l|l|l|}
\hline Description of the area to which they report & Frequency & $\begin{array}{l}\text { Relative } \\
\text { Frequency }\end{array}$ \\
\hline General Administration Coordination & 1 & $1 \%$ \\
\hline Department of Social Communication & 1 & $1 \%$ \\
\hline Office of the Municipal Presidency & 1 & $1 \%$ \\
\hline Treasury Administration and Monitoring Department & 1 & $1 \%$ \\
\hline Direction of Planning and Communication & 1 & $1 \%$ \\
\hline Direction General of Public Safety and Traffic & 1 & $1 \%$ \\
\hline Office of the Mayor & 1 & $1 \%$ \\
\hline Department of Materials Resources & 1 & $1 \%$ \\
\hline Municipal president & 4 & $4 \%$ \\
\hline without area of Information Technology or similar & 71 & $74 \%$ \\
\hline Secretary of Administration & 3 & $3 \%$ \\
\hline Secretary of Administration and Finance & 1 & $1 \%$ \\
\hline Secretary of the Town Hall & 3 & $3 \%$ \\
\hline Sub coordination of Social Development & 1 & $1 \%$ \\
\hline Admissions and Innovation Branch & 1 & $1 \%$ \\
\hline Municipal Treasury & 4 & $4 \%$ \\
\hline Total & 96 & $100 \%$ \\
\hline & & \\
\hline
\end{tabular}

Source: Own (2017)

Another important aspect to analyze is the area to which the Information Technologies or related within the municipal structure. As can be seen in Table 11, only 4\% report to the presidency, followed by the Municipal Treasury with the same percentage and 3\% to the City Hall Secretariat. While this is not good or bad, it is important to mention that the more hierarchy the IT area has, the more interference it has in decision making, authority and responsibility. 


\section{Proposal Of A Specialized Organizational Structure To Satisfactorly Incorporate Information Technologies}

Una vez que se ha llevado a cabo el análisis de la información histórica y teórica de las estructuras organizativas, y se ha realizado la investigación documental y de campo, se propone una estructura organizativa municipal para incorporar las Tecnologías de la Información. La estructura organizativa propuesta en la administración pública municipal, consta de 3 fases que se deben al crecimiento en la complejidad de las organizaciones, así como a la incorporación de Tecnologías de la Información.

Phase 1. Inclusion of an area of Information Technologies. The transcendence of the proposal, lies in the strategic incorporation of the information technologies as part of the organizational structures of the local government. Derived from the above, its detail the proposal.

Proposal one organizational structure strategic:

- Proposal of positions, functions, obligations and responsibilities, with the normative support

- Suggestion of interaction that will have the organizational structure

- Analyses cost/ benefit of the proposal.

- Normative strategies for the collaboration of the proposal in the decision making like: municipal programs, municipal plan of development, municipal band, regulations, among others.

- Suggestions in the distribution of municipal budget, for the works strictly of technological modernization through, the systematization of administrative process and operatives, as well as systems of strategies support

- Proposal of processes that stimulates the transparency in the activities and process, per the laws, propitiating well the feedback and increase the credibility with the citizens

- Propitiate through administrative and technological conceptual models, the viability of information among the municipal dependencies and citizens, backed with the normative framework corresponding

- Propose program, aligned to the normative framework for increase gradually the efficiency and efficacy in the municipal processes, for offer a best service to the citizens, and internally generate a web of knowledge of information

- Recommend reengineering of process, and therefrom, propose corrections, delete duplications of the functions areas, with the goal to maximize the resources and speed up the benefit of the local public services

- Recommend through different technologies platforms, the interaction between the municipal authorities and the citizens 
- Backed the proposal, supported for the regulatory framework, or in failing proposal a series correction with the goal of include of the information technologies in the municipal environment satisfactorily

- Process of strengthening for the incorporation of the information technologies in the local organizational structures

It shows the next conceptual diagram the proposal (According the Ilustration 5).

Ilustración 5. Organizational structure of the proposal

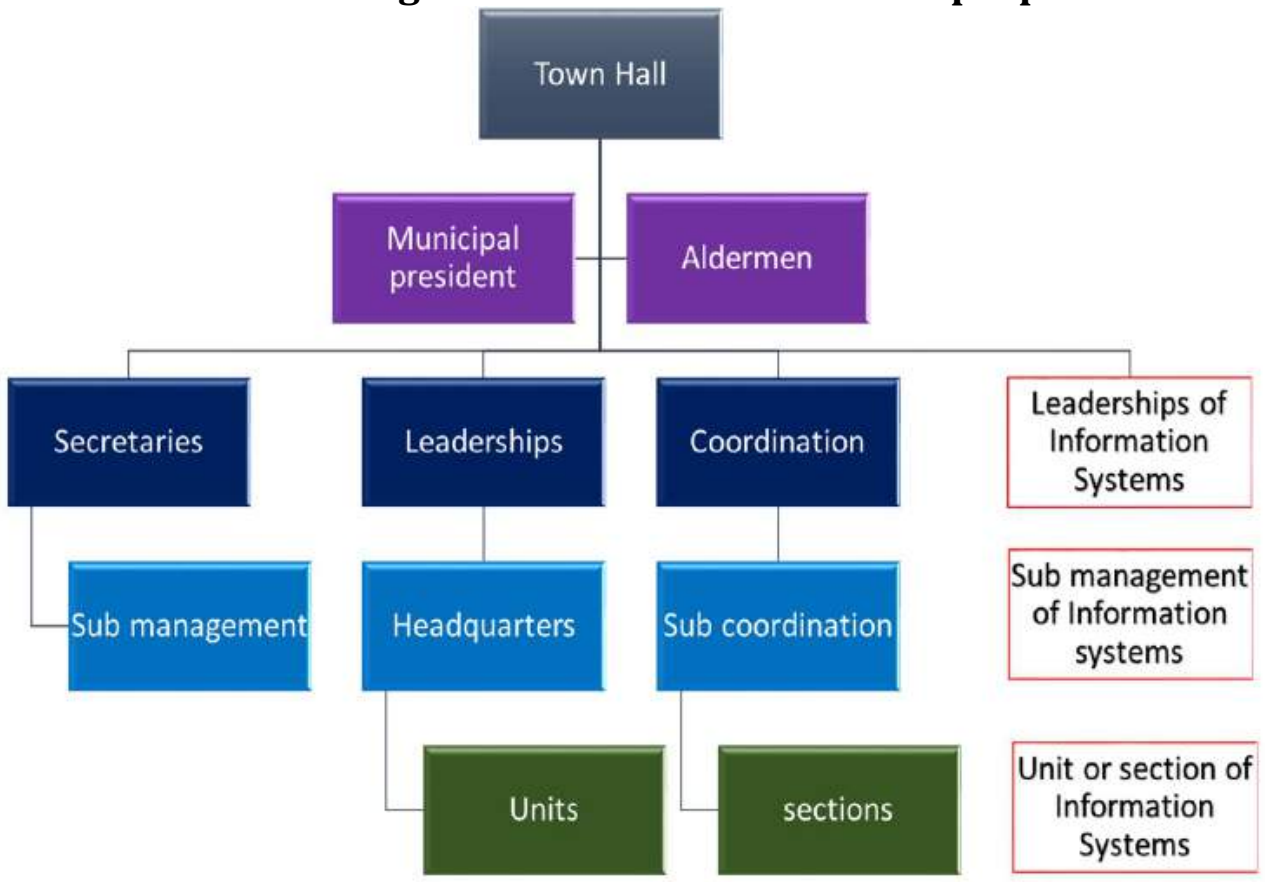

Source: own (2017), take as references: Municipal Organic Law of the State of Mexico, Municipal laws (2013) and Internal regulations (2013) of the municipals.

As can be seen in Illustration 5, it is suggested to start with an Information Technology section, and depending on the degree of assimilation and use (adapt UN evo - lution indicators), increase the hierarchy to Directorate or Secretary with direct report to the municipal presidency.

Phase 2. Evolution of Simple, Functional and Divisional Structures to Network Structures. Although the complexity of the organization is an important factor for structures to evolve, from my point of view, they can initiate the transition from simple, functional and divisional Structures to Network structures where the current functions will not be lost, rather it will have an interaction with the other areas in a permanent way to collaborate with the achievement of the general objective.

As can be seen in Illustration 6, the municipal structure is organized in such a way that the secretariats, management and other areas remain with the same hierarchical level as they had in simple, functional and divisional structures. What is added is the interaction and service provided between the areas, which will be reflected in a better communication, giving rise to feedback, complementing ideas and knowledge without losing authority and functions. On the 
other hand, it is important to point out that the normative part must be modified according to the suggestion of areas and their interaction, in order to delimit their interrelation and scope.

The application of the Network structure depends on the maturity in the application of phase 1 (See Illustration 5), where it is necessary to elevate the Information Technology Department with a direct report to the municipal presidency, in addition to the Technological infrastructure needed to support the change to a Network structure.

\section{Illustration 6. Network Organizational Structure}
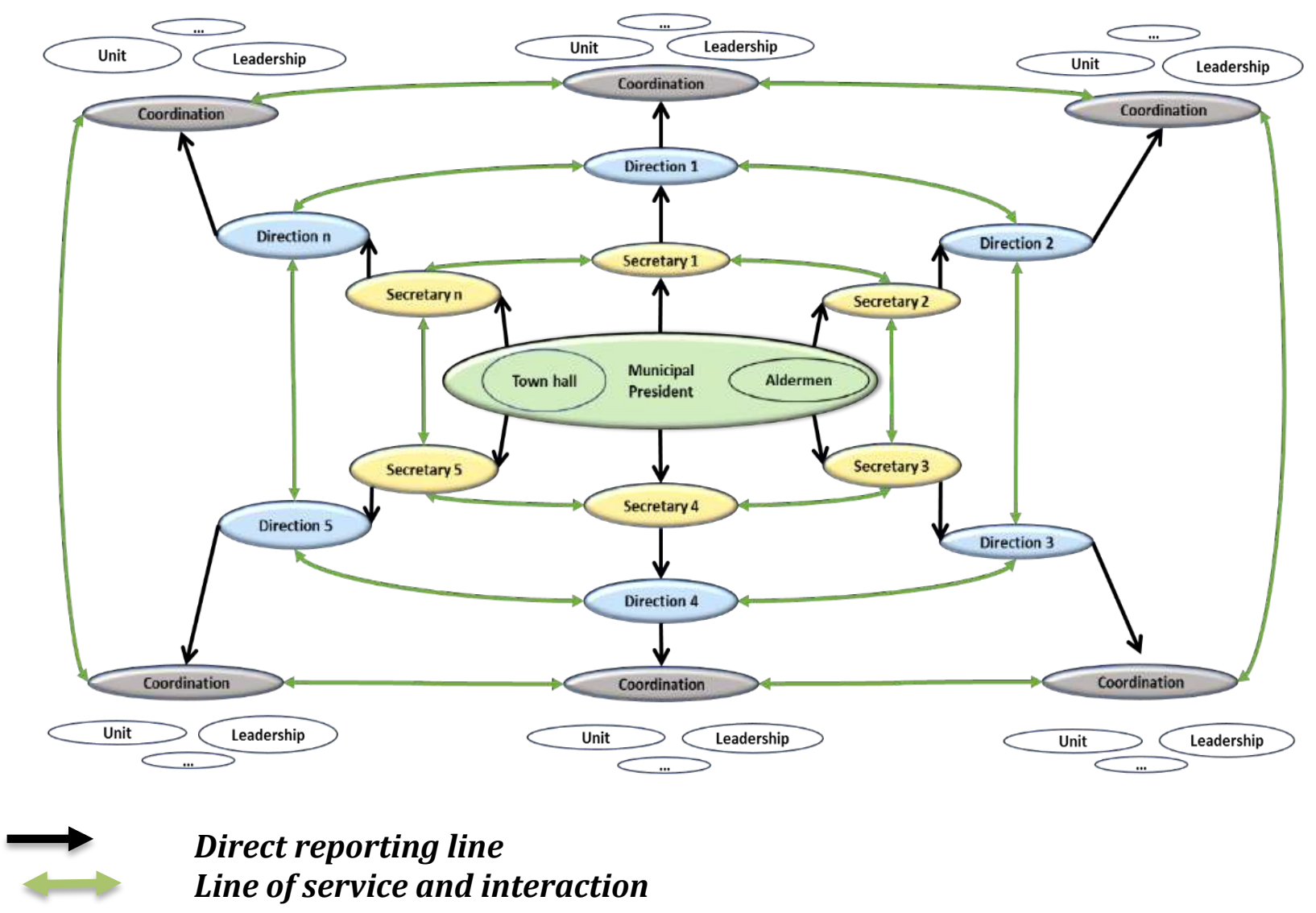

Direct reporting line
Line of service and interaction

Source: Own (2017)

Phase 3. Network and Virtual Structure. In this phase, it is important to assess the maturity of phase 2 (through e-government indicators, suggested by the UN [44]), where the degree of maturity will result in a Network and virtual structure. Where Information and Communication Technologies play an important role. Given the nature of this research will focus only on information technologies.

As can be seen in Illustration 7, the basis and support of the proposal is the Network structure, and in it are added virtual structures with the possibility of interacting and covering the fourdimensional needs of e-government [44]:

1. Government to Government

2. Government to Citizen

3. Government to Enterprice 


\section{Government to Employee}

This model will generate knowledge networks, databases and interaction between different factors, which will allow the analysis of information for long-term decision-making (See Illustration 7).

\section{Illustration 7. Organizational Structure of Red - Virtual}

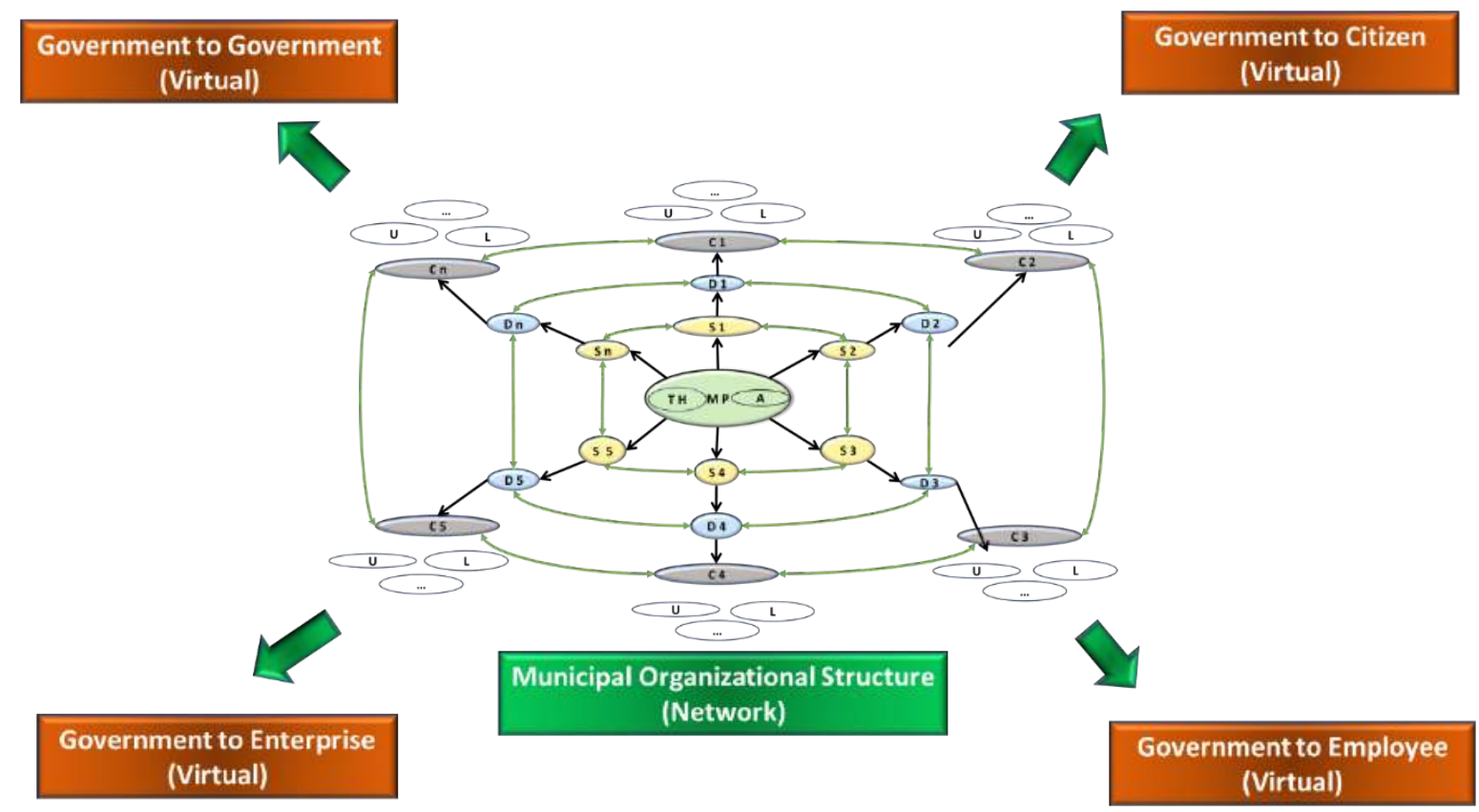

Source: Own (2017)

Finally, the transition times between the phases, depends on the complexity of the organizations, where the planning and the creation of the infrastructure would sufficiently robust to give opportunity to the evolution of the structures.

\section{CONCLUSION}

Municipal organizational structures, although complex and based on the normative framework in which their attributions are delineated, is important to modernize given the problems they face in increasing demand for public services and scarce resources. In this sense, Information Technologies, are an important alternative solution to this problem. However, for its optimal functioning, it is necessary to have technological infrastructure and an organizational structure in which it is sought to participate in the making of municipal strategic decisions. For this purpose, it is suggested to create a Figure of Direction or Secretary of Information Technologies (See Illustration 5) in the organization chart, which may have decision making and direct interference in municipal planning, and then evolve to phases 2 and 3 (See Illustrations 6 and 7)

\section{References}

Pérez, Camacho, Mena \& Arroyo (2016), Analisis General del Gobierno Electrónico en México, Revista de Tecnología y Sociedad, Núm9, Vol 5, Universidad de Guadalajara

Terry \& Flanklin (1977), Principios de Admnistración, CECSA, México,p. 44

Hall (1985), Organizaciones, estrucura y proceso, Prentice / Hall Internacional, España

Bertalanffy Ludwig Von (1976). Teoría general de los sistemas: Fundamentos, desarrollo, aplicaciones. México: Fondo de cultura Económica; 1976. p 94. 
Galván, I. P., \& Pizano, J. C. (2017). Organization Structure Municipally, Ready To The Organizational Incorporation Of The Information Technologies? Advances in Social Sciences Research Journal, 4(4) 125-145

Blau, Peter M (1974) On the NatureofOrganizations. Nueva York: John Wiley and Sons, p.12

Ranson, Stewart, Bob Hinings Y Royster Greenwood (1980), The Structuring of Organizational Structures, AdministrativeScience Quarterly, 25, No. 1, 1-17

Ackoff Russell (1996) Concepto cambiante de planeación, Limusa, México

Gonzalez Monroy (1999) Manuales estrategicos, Julio, Méico, p. 5

Bueno Campos, E. (2007) Organización de empresas; Estructura, procesos y modelos. Editorial Pirámide, 2ª Edición

Valenzuela (2013), La evolución del diseño y la estructura organizativa, Universidad Autónoma de Barcelona, Barcelona

Padilla Meléndez Antonio, Del Águila Obra, Ana Rosa (2003), La evolución de las formas organizativas. De la Estructura simple a la organización en Red y Virtual, Investigaciones Europeas de Dirección y Economía de la Empresa, Vol. 9, N³, 2003, pp. 69-94 ISSN: 1135-2523

Mintzberg, H. (1983): Power in and Around Organizations. Prentice Hall, Englewood Cliffs. Edición española: El poder en las organizaciones. Ariel, Barcelona, 1992

Malone, T.W. y Rockart, J.F. (1991): "Cornputers, Networks and the Corporation". Scientific American, 265 (3), pp. 92-99.

Huber, G.P. (1984): "The nature and design of post-industrial organizations". Management Science. Vol. 30, n" 8, August, pp. 928-951.

Ackoff, R. (1989): "The circular organization: An update". Academy of Management Executive, 3 (1), pp. 11-16.

Malone, T.W.; Yates, J. Y Benjamin, (1987): "Electronic Markets and Electronic Hierarchies". Communications of the ACM, 30, pp. 484-496.

Ouchi, W.G. (1980): "Markets, Bureaucracies and Clans". Administrative Science Quarterly, n? 25, pp. $129-141$.

Hedlund, G. (1986): "The Hypermodern MNC-A Heterarchy??". Human Resource Management. 25 (1), pp. 9-35.

Miles, R.E., Snow, C.C. (1986): "Organizations: New Concepts for New Forms". California Management Review, vol. XXVIII, n 3 , Spring, p. 62-73.

Eccles, R.G, y crane, D.B, (1987): "Managing Through Networks in Investment Banking". California Management Review, otoño.

Barlett, c.A. y Ghoshal, S. (1993): "Beyond the M-form: Toward a Managerial Theory of the Firm". Strategic Management Iournal. 14. pp. 23-46.

Handy, e. (1992): "Balancing Corporate Power. A New Federalist Paper". Harvard Business Review, vol. 70, nº 6, pp. 59-72.

Badaracco, J.L. (1991): The Knowledge Link: How Firms Compete throught Strategic Alliances. Harvard Business School Press. Boston. Massachussets.

Miles, D.Q. (1991): Rebirth ofthe Corporation. Wiley \& Sons. Nueva York.

Wagner, H.E. (1991): "The Open Corporation". California Management Review. Sumrner, pp. 46-60.

Davidow, W.H. y Malone, M,S, (1992): The Virtual Corporation: Structuring and Revitalizing the Corporation for the 21st Century. Harper Collins Pub., Nueva York.

Bridges, W. (1994): "The end of the job". Fortune International, vol. 130, n 6, 19 de septiembre, pp. 46-51.

Snow, C.C.; Miles, R.E. Y Coleman, H.J. (1992): "Managing 21st. Century Network Organizations". Organizational Dynamics. Vol. 20, n" 3, invierno.

Quinn, J.B. (1992): Intelligent Enterprise: A knowledge and Service Based Paradigm for Industry.The Free Press. New York.

Burris, B.H. (1993): Techonocracy. State University of New York Press. New York.

Ostroff, F. y SMITH, D. (1992): "The Horizontal Organization". Mckinsey Quarterly, n? l. Versión española: "La organización horizontal". Harvard Deusto Business Review, n4,1993; pp. 4-19. 
Heckscher, C. (1994): "From Hierarchy to Enterprise: Internal Markets are the new Foundation of Management". Academy of Management Executive, 8 (4).

Hedlund, G. (1994): "A model of knowledge Management and the N-Form corporation". Strategic Management Journal. Vol. 15, pp. 73-90.

Galbralth (1994): Competing witn Flexible Lateral Organizations. Addison-Wesley. 2" ed .. Bastan.

Nonaka y Takeuchi, H. (1995): The Knowledge Creating Company. Oxford University Press. Nueva York

Ciborra (1996): "The platform organization: recombining strategíes, structures, and surprises". Organization Science,7 (2), pp. 103-118.

Lucas (1996): The T-Form Organization. Jossey-Bass. San Francisco.

Milles, R.; Snow, c.c.. Mathews, J.A.; Miles, G.; y Coleman, H.J. (1997): "Organizing in the KnowledgeAge: Anticipating the Cellular Form". Academy of Management Executive, 11 (4), pp. 7-20.

Morales (1999): "Diseño de organizaciones permanentemente adaptables: estructuras fractales". Alta Dirección. W 204, pp. 165-177.

Carry, K. M. (1999): "Organizational Change and the Digital Economy: A computational Organization Science

Rockart, J.F. y Short, J.E. (1989): "IT in the 19905: managing organizational interdependence". Sloan Management Review, 30, winter, pp. 7-17.

Travica, B. (1997): "The Design of the Virtual Organization: A Research Model". Papers of 1997 Americas Conference on Information Systems. Association for Inforroation Systems. Indianapolis (Indiana, USA).

Palmer, J.w. y Speier, e. (1997): "A Typology of Virtual Organizations: An Empirical Study". Papers of 1997, Americas Conference on Information Systems. Association for Information Systems. Indianapolis (Indiana, USA).

United Nations. (2014). United Nations e-government Survey. Estados Unidos de America.

OEA. (2010). Foro e-Gobierno OEA. Canada: OEA

OCDE. (2005). e-Government for Better Government. Francia: OECD Publications

CEPAL. (2006). Hacia una política de innovación eficiente en América Latina. CEPAL

Gobierno de la Republica. (2013). Plan Nacional de Desarrollo 2013 - 2018. Ciudad de México

Instituto Nacional para el Federalismo y el Desarrollo Municipal (2014), Resultados del programa "Agenda para el desarrollo municipal 2014", SEGOB, México

Fernández, Narez, \& García. (2008). Metodología de la investigación en ciencias sociales (págs. 54 - 58). México: Grupo Editorial Patria.

Castillo de la Peña. (2010). En Metodología para la elaboración del trabajo científico (págs. 228 - 229). México: Instituto Politécnico Nacional. 